\title{
Degradation of 4 tropical forages in the rumen in cows
}

\author{
P Cerneau, A Xandé, G Aumont \\ INRA, Antilles Guyane, station de Recherches zootechniques BP 1232, \\ 97185 Pointe-à-Pitre Cedex, French West Indies
}

Three cows fitted with rumen cannulae were used. They were fed with $5 \mathrm{~kg}$ dehydrated lucerne and Digitaria decumbens hay ad libitum. Nitrogen degradation (Michalet Doreau et al, 1987) of King Grass (stems or leaves), Brachiaria ruzzisiensis (whole plant or stems, 4 months of regrowth age), Arachis leaves and Enthrina poepygiana leaves were studied with the standardized in sacco technique. Following incubation, the bags were washed (cold water and ultrasonic bath), then dried. Nitrogen degradation kinetics were described by a single exponential model: $D(t)=a+b\left(1-e^{-c t}\right)$ and $n D=a+b c /(c+$ k) $(k=0.06 / h)$.

The trend regarding nitrogen and DM disappearance was similar to that described in the literature. The nitrogen degradability of King grass stems could be explained by linkage with undegradable components (table I); furthermore, the very low nitrogen level in this sample $(<5 \mathrm{~g} / \mathrm{kg} \mathrm{MS})$ was very difficult to detect accurately. Arachis leaves were the most rapidly degraded $(c \approx 0.12 / h)$. The nitrogen theoretical degradation (nDT) of Erythrina was only $53 \%$. The $\mathrm{nDT}$ of the 4 tropical forages was very variable and low, similar to that recorded for Pangola and leguminous trees reported by Aumont et al (1992). Therefore, it appears necessary to correct the single $\mathrm{nD}$ data $(65 \%)$ for all tropical forages recommended by Xandé et al (1989).

Aumont G, Saminadin G, Cerneau P, Xandé A (1992) J Agric Sci (Camb) (in press)

Xandé A, Garcia-Trujillo R, Caceres O (1989) Ruminant Nutrition: Recommended Allowances and Feed Tables (Jarrige R, ed) INRA, 147, rue de l'Université, 75007 Paris

Table I. Non-linear regression parameters for DM and nitrogen degradation.

\begin{tabular}{|c|c|c|c|c|c|c|c|c|}
\hline & \multicolumn{4}{|c|}{ Dry matter } & \multicolumn{4}{|c|}{ Nitrogen } \\
\hline & $\begin{array}{c}a \\
(\%)\end{array}$ & $\begin{array}{r}b \\
(\%)\end{array}$ & $\begin{array}{c}c \\
(\% / h)\end{array}$ & $\begin{array}{c}D T \\
(\%)\end{array}$ & $\begin{array}{c}a \\
(\%)\end{array}$ & $\begin{array}{c}b \\
(\%)\end{array}$ & $\begin{array}{c}c \\
(\% / h)\end{array}$ & $\begin{array}{l}D T \\
(\%)\end{array}$ \\
\hline King grass stems & 14.6 & 37.4 & 4.1 & 29.9 & 0.0 & 6.6 & 0.0 & 0.0 \\
\hline King grass leaves & 11.9 & 62.9 & 2.9 & 32.4 & 23.9 & 50.7 & 12.7 & 39.6 \\
\hline Arachis leaves & 34.4 & 47.3 & 12.4 & 66.3 & 29.8 & 59.8 & 1.9 & 69.6 \\
\hline Brachiaria ruzzisiensis $4 \mathrm{M}$ & 21.2 & 55.8 & 7.9 & 52.9 & 18.6 & 61.8 & 9.7 & 56.7 \\
\hline Brachiaria whole & 21.2 & 55.3 & 7.4 & 51.6 & 21.6 & 58.1 & 9.9 & 57.9 \\
\hline Erythrina & 34.3 & 25.0 & 6.9 & 47.7 & 39.0 & 26.1 & 6.5 & 52.6 \\
\hline
\end{tabular}

